\title{
Studielederen. Nyttig idiot eller maskinmester?
}

\author{
Finn Wiedemann, lektor, Institut for Kulturvidenskaber, Syddansk Universitet
}

Videnskabelige artikel, fagfællebedømt

Formålet med artiklen er at identificere erfaringer med studieledelse på danske universiteter og diskutere de udfordringer og perspektiver, det har for varetagelse af funktionen med at sikre kvalitet og udvikling af universitetets undervisning og uddannelser. Empirisk tages der afsæt i studielederes selvrapporterede erfaringer. Analytisk inddrages bl.a. metaforanalyse inspireret af organisations- og ledelsesstudier. Artiklen peger på, at studieledere primært arbejder med drift og tilpasning og kan karakteriseres som mellemledere uden formel kompetence. Konsekvensen er, at studieledere har dårlige muligheder for at varetage studiemæssige hensyn og interesser, fordi de står $i$ en svag position over den stigende mængde krav og forventninger, de mødes med fra universitetets øvrige ledelse og omverdenen. Som en mulig løsning på denne problemstilling anbefales en professionaliseringsstrategi.

\section{Indledning}

Artiklen har til hensigt at analysere erfaringer med studieledelse på danske universiteter, herunder indkredse hvad det er for en ledelsesrolle, som studieledere varetager. Formålet er at diskutere de udfordringer og perspektiver, det har for studieledernes varetagelse af funktionen med at sikre kvalitet og udvikling af universitetets undervisning og uddannelser.

Indledningsvis beskrives den kontekst, som studieledelse udspiller sig inden for. En kontekst, som overordnet bærer præg af den modernisering, som den offentlige sektor siden begyndelsen af 80'erne, og konkret universiteterne, har gennemgået de seneste 10-15 år. Vilkårene for studieledelse har ændret sig, sådan at studieledere i langt højere grad end tidligere mødes med centrale tiltag og initiativer.

I det efterfølgende afsnit analyseres empirien, som består af 20 studielederes skriftlige beskrivelser af deres jobsituation. Analysen fokuserer på, hvad det er for en identitet og selvforståelse, man har som studieleder. Analysen fokuserer endvidere på forholdet til de forskellige interessenter, som studielederne samarbejder med, f.eks. studerende, administration og ledelse.

Analysen peger på, at studielederne kan karakteriseres som mellemledere, som primært beskæftiger sig med faglige driftsledelse. I bedste fald er de en slags maskinmestre og brobyggere, som sørger for, at det daglige uddannelsesmaskineri fungerer til gavn for de forskellige interessenter. I værste fald er de en art nyttige idioter eller universitetspedeller, hvis væsentligste opgave er at implementere centrale tiltag og løse allehånde små og store problemer.

Studieledernes ambivalente erfaringer med studieledelse kan fortolkes i sammenhæng med den nævnte moderniseringsdagsorden.

I artiklens sidste afsnit peges der på, hvilke perspektiver studiet har givet anledning til. Der argumenteres for, at der er behov for en professionaliseringsstrategi, sådan at studielederne bl.a. får bedre mulighed for at varetage studiemæssige og strategiske hensyn som kontrast til den nuværende situation. 


\section{Empiriske og metodiske refleksioner}

Empirisk tages der afsæt i selvrapporterede oplevelser og erfaringer med studieledelse. I forbindelse med et studielederseminar om studielederfunktionens omfang, opgaver og udfordringer, som blev afholdt på et dansk universitet i eftersommeren 2016, var en række studieledere på forhånd blevet bedt om at svare på forskellige skriftlige spørgsmål. Spørgsmålene tematiserede erfaringer og oplevelser med studieledelse, f.eks. tids- og opgaveforbrug og eventuelle ændringer heri, ligesom de blev bedt om at beskrive de opgaver, de fandt mest relevante og meningsfulde samt det modsatte.

I alt 20 studieledere besvarede opfordringen. Nogle af besvarelserne var relativt detaljerede og fyldte fire til fem A4-sider. Andre var kortfattede og blot på en enkelt side. Aldersmæssigt er studielederne cirka 40-65 år, og kønsfordelingen nogenlunde ligelig. Studieledernes anciennitet spænder fra et til to år og til cirka ti år. De studieledere, som indgår i analysen, arbejder alle under en decentral model. Ingen af dem er således fuldtidsstudieledere, men varetager i varierende grad også opgaver, der knytter sig til undervisning og forskning.

Den metode, som er anvendt til dataindsamling, kan kaldes selvevaluering eller dokumentation af egen praksis. Målet har i første omgang ikke været, at datagrundlaget skulle anvendes i et forskningsperspektiv.

Nogle studieledere kan derfor i princippet have haft en interesse i at tegne et "taktisk" billede af deres arbejdssituation for at signalere til ledelsen, at der burde ændres i deres opgaver, og at de skulle have flere timer eller mere i løn for at udføre funktionen.

\section{Refleksioner over analyse og teori}

Analytisk vil der blive taget afsæt i dokument- og tekstanalyse. Studieledernes selvrapporterede beskrivelser kan siges at udgøre tekster. Med afsæt i en fænomenologisk inspireret tekstanalyse (Vosmer, 1969) vil en indkredsning af studieledernes erfaringer med deres arbejdssituation blive fremanalyseret: Hvad er det for grundlæggende ideer og forestillinger, som karakteriserer deres erfaringer med studieledelse, og som kommer til udtryk i de nævnte afrapporteringer? Et formål med analysen vil særskilt være at se på de metaforer, som studielederne bruger, når de beskriver deres arbejdssituation (Alvesson \& Spicer, 2011; Lakoff \& Johnson, 2002; Morgan, 1997; Schultz, 2000).

Et udgangspunkt for at beskæftige sig med metaforer er, at vi ikke har direkte adgang til virkeligheden, men at denne altid er sprogligt medieret (Morgan, 1997; Lakoff \& Johnson (2004). I forhold til at beskrive livet i organisationer med afsæt i metaforer har Gareth Morgans (1997) arbejde være banebrydende. Metaforer bliver en måde at se og tænke om organisationer på. Hatch et al (2006) og Alvesson \& Spicer (2011) har bl.a. med inspiration herfra arbejdet med metaforanalyse i forhold til at indkredse og forstå lederes virkelighedsopfattelse.

Konkret giver metaforanalysen mulighed for at afdække og identificere den mening og betydning, studielederne tillægger deres job, ved f.eks. at lede efter de metaforer, de benytter i de tekster, de har produceret.

Med afsæt i analysen vil metaforer, der kredser om henholdsvis tid, rum, omverden (forholdet til de andre) og jeg (identitet) blive identificeret. Tid, rum, jeg og omverden udgør grundlæggende 
måder, hvorpå vi som mennesker strukturerer og ordner vores verden (Vosmer, 1969; Gullestrup, 2003; Levi Strauss, 1994).

Alvesson \& Spencer (2011) nævner tre måder, hvorpå metaforer rent analytisk kan bruges. Henholdsvis konceptuel metaforteori inspireret af Lakoff og Johnson (2004), hvor analytikeren fors $\varnothing$ ger at identificere de dybere underlæggende metaforer i teksten, og korrespondanceanalyse, hvor analytikeren leder efter konkrete metaforer i sit empiriske materiale. F.eks. omtaler flere af de interviewede studieledere studielederen som en person, der arbejder i maskinrummet og får ting til at ske. Den tredje måde er domæne-interaktions-analyse. Analytikeren konstruerer her de metaforer, som passer bedst på materialet eller situationen. Dette giver analytikeren mulighed for at bruge metaforer på kreative måder med henblik på at forstå et fænomen på nye og interessante måder, f.eks. vil metaforen studielederen som pedel blive anvendt. Ved at anskue studielederen som pedel skabes der en ny måde at anskue studieledelse på.

De to sidstnævnte fremgangsmåder vil blive benyttet $\mathrm{i}$ analysen.

Metaforanalysen befinder sig inden for en normativ og en kulturorienteret tradition vedr. studiet af organisationer (Sørensen (red.) et al, 2016; Schultz, 2000). Virkeligheden er socialt konstruereret, og analytikerens opgave bliver at afdække aktørernes mening og betydning.

Sidst i artiklen vil der, i det mere diskussionsorienterede afsnit, blive anlagt et mere politisk eller konfliktorienteret perspektiv. I organisationer kæmper forskellige aktører om magt og indflydelse, f.eks. ledelse og medarbejdere. Mere konkret vil det blive diskuteret, hvilke barrierer og muligheder studiet har givet anledning til i forhold til muligheden for at varetage funktionen som studieleder (Borum, 2013).

\section{Studielederen}

Studielederen er en særlig universitær konstruktion. Det er en funktion med mange opgaver og meget ansvar, men med lille formel kompetence og ingen ledelsesret $\mathrm{i}$ forhold til økonomi og personale. Rent lovgivningsmæssigt er formuleringerne i universitetsloven yderst sparsomme om, hvad studielederens opgave og ansvar er. Det hedder her:

Studielederen har til opgave i samarbejde med studienæunet at forestå den praktiske tilrettelæggelse af undervisning og af prøver og anden bedømmelse, der indgår i eksamen. Studielederen godkender opgaveformulering og afleveringstidspunkt for kandidatspecialet samt i tilknytning hertil en plan for vejledningen af den studerende. (https://danskelove.dk/universitetsloven)

I ledelsestermer kan studielederen forstås som en mellemleder placeret mellem ledelseslag som dekan, institutleder og VIP'ere og TAP'ere. Man er leder over nogen, men bliver samtidig ledet af andre. Studielederne forventes at lede VIP- og TAP-personale, der formelt bliver ledet af f.eks. institutledere og administrationschefer. Studielederen har hverken budget- eller personaleansvar. Vedkommende har f.eks. ikke en selvstændig økonomi og mulighed for at belønne, straffe eller formulere målsætninger eller succeskriterier på hele institutionens vegne eller rekruttere fast personale, sådan som "rigtige" ledere ofte har (Frederiksen, 2016). ${ }^{i}$

Der er relativt stor forskel på, hvordan de forskellige universiteter og fakulteter har valgt at organisere studieledelsen, ligesom der internt på det enkelte universitet findes forskellige organisationsformer. Man kan her tale om henholdsvis en central og en decentral model. Som et eksempel på et universitet, som både har en central og en decentral model, kan nævnes Syddansk Univer- 
sitet, hvor f.eks. humaniora har valgt en decentral model, mens det tekniske og naturvidenskabelige fakultet benytter en mere central model.

I den centrale model vil studieledelsen typisk være en del af ledelsen, dog uden at have ledelsesret og personaleansvar. Studielederen er her fuldtidsstudieleder med ansvar for mange uddannelser og skal så samarbejde med f.eks. en uddannelseskoordinator, som er tæt på det daglige studie- og uddannelsesmiljø.

I den decentrale model vil studielederen ikke være en del af ledelsen, men have ansvar for en eller få uddannelser og måske have en fjerdedel af sin arbejdstid til rådighed for studieledelse. I udgangspunktet giver det nogle ret forskellige vilkår for at udøve studieledelse og dermed forskellige barrierer og muligheder.

\section{Universitetets udvikling}

I det følgende skal universitetets historiske udvikling kort beskrives. Formålet er at identificere de rammer og vilkår, som studieledelse aktuelt fungerer under.

I 1970/73 kom en ny universitetsstyrelseslov, som erstattede det, som lidt foragteligt var blevet benævnt som professorvælde. Professorvældet blev afløst af det kollegiale selvstyre, som sikrede universitetets ansatte direkte indflydelse på økonomi, ansættelser og studierelaterede spørgsmål. En nyskabelse var studienævnet, som fik en central placering og bl.a. indflydelse på ansættelser.

I 1993 blev universitetsstyrelsesloven erstattet af universitetsloven, som indskrænkede det kollegiale selvstyre, og hvor der i stedet blev lagt vægt på de enkelte lederes ansvar og kompetence. Studienævnenes funktion forblev uændrede, dog med den undtagelse, at formanden for studienævnet blev studieleder.

I 2003 trådte en ny universitetslov i kraft. Med 2003-loven blev de gamle valgte ledere afløst af ansatte ledere, således rektor, dekan og institutleder. Det kollegiale selvstyre forsvandt således og blev erstattet af en mere hierarkisk og enstrenget ledelsesform (Knudsen, 2007; Wright, 2014).

En undtagelse herfor er dog studielederen, som fortsat ideelt set vælges i en kvasi-demokratisk proces. Som studieleder indstilles man af studienævnet, hvorefter dekanen formelt set godkender denne indstilling. Studielederen refererer som forsker til institutlederen og som studieleder til dekanen eller prodekanen og er underlagt disse. Ud fra et ledelsesmæssigt perspektiv sker der med 2003-loven en svækkelse af studielederfunktionen, mens dekan og institutleder formelt set bliver styrket (Harboe, 2013, s. 108).

Overordnet set er det rektor, der har det formelle ansvar for uddannelse, herunder evaluering, mens studieledere og studienævn skal inddrages, som der står i lovteksten. Typisk er ansvaret så delegeret ud til dekaner og institutledere. I praksis har studieleder og studienævn de fleste steder ansvaret for den daglige tilrettelæggelse af uddannelse og eksamen. Baggrunden for den pågældende arbejdsdeling er blandt andet, at institutlederen har personaleansvaret. Er der problemer med undervisning og evaluering, er det institutlederen, som har det formelle ansvar til at få løst opgaven og f.eks. pålægge undervisere opgaver eller påtale fejl og mangler. 


\section{Den offentlige sektor i øvrigt}

Den udvikling, som universiteterne har været igennem, svarer med forskellige modifikationer til den udvikling, den øvrige offentlige sektor har været igennem. Alle de elementer, som indgår $\mathrm{i}$ New Public Management, kan genfindes i måden, universiteterne har udviklet sig på, f.eks. øget markedsorientering og output- og resultatstyring samt fokus på professionel ledelse med klart ledelsesansvar (Hood, 1991, Klaudi Klausen \& Ståhlberg, 1999, Wiedemann, 2016).

Særskilt for universiteterne gælder det, at de i løbet af de seneste 10-15 år indholdsmæssigt også har skullet orientere sig hen imod det globale videns- og konkurrencesamfund. En konsekvens af dette er, at en mere strategisk og anvendelsesorienteret forskning har set dagens lys, såkaldt modus 2-forskning (Gibbons et al, 1994), ligesom samarbejdsformer med omverdenen, f.eks. industrien, er blevet prioriteret højt. De nye ledelses- og styringsformer har været et redskab i denne transformation hen imod masse- og mere markedsorienterede universiteter (Ball, 2012; Wright, 2014).

Generelt er der sket en bevægelse fra kollegialt selvstyre hen imod en stigende virksomhedsliggørelse, hvor universiteterne på en række måder er kommet til at minde om den måde, private virksomheder er organiseret på: professionelle bestyrelser med ekstern flertalsrepræsentation, direktion, åremålsansatte ledelser med tydeligere ansvar og kompetence, hvor hensyn til økonomisk tænkning, målbare resultater og strategisk udvikling spiller en stadigt st $ø$ rre rolle.

I organisatorisk forstand har universiteterne på den ene side fået større autonomi som en konsekvens af den nævnte virksomhedsliggørelse, men på den anden side er der sket en stigende recentralisering, hvor detaljerede udviklingskontraker og forskellige relativt konkrete former for outputstyring indsnævrer universiteternes autonomi og manøvrefrihed. Pedersen (2008) taler om tendensen hen imod både re-centralisering og øget selvstyre som noget, der under ét karakteriserer den offentlige sektor.

Som studieleder har man ikke oplevet den $\emptyset$ gede autonomi, som virksomhedsligg ørelsen har medført. Denne er forbeholdt topledelsesniveauet, som i stigende grad har fået mulighed for at agere strategisk og udviklingsorienteret. I stedet har man i høj grad mærket tendensen til $\varnothing$ get re-centralisering, hvor en række nye centrale opgaver og reformer, især de senere år, har sat rammerne for studieledelsens arbejde. Det gælder dels nye eksterne krav, dels nye interne krav fra universitetsledelse og fakultetet som en konsekvens af virksomhedsliggørelsen.

Eksternt har f.eks. studiefremdriftsreformerne pålagt studienævn og studieledere mange nye opgaver med at tilpasse uddannelser og pædagogik til de ændrede studievilkår. Af særlige interne konsekvenser for studieledelse kan nævnes det kvalitetsarbejde, som universiteterne har igangsat som led i deres interne akkreditering. Typisk vil man skulle dokumentere, at man arbejder med det særlige kvalitetskoncept, som det enkelte universitet har udviklet, ligesom man er forpligtet til at tage afsæt i forskellige output-tal vedr. f.eks. frafald, forsinkelse og beskæftigelse som baggrund for indsatser og tiltag.

Internt på universiteterne har der de senere år tillige været stigende optagethed af, hvordan man særskilt kan udvikle markante selvstændige profiler, som f.eks. knytter sig til pædagogik, fagpakker, internationalisering, innovation, talentudvikling og employability.

I mange tilfælde har det været studienævnet, og i praksis ofte studielederne, som har haft til opgave at implementere de mange nye reformer og tiltag og fors $\varnothing$ ge at få dem tilpasset studie- 
ordninger og uddannelser. Studieledernes rolle har her været at skulle virke som agent for principaler som ministerium, universitetsledelse og fakultet.

Set fra studieledelsens perspektiv er den politiske og administrative styring taget mærkbart til de senere år, sådan som det i øvrigt kan opleves af mange andre aktører inden for den offentlige sektor (Nørgaard og Kaspersen, 2015; Wiedemann, 2016).

\section{Analyse: Tid}

I det følgende skal analysen af studielederens erfaringer med at varetage studielederfunktionen formidles. Tid udgør et ordningsprincip i forhold til, hvordan man disponerer, strukturerer og erfarer sin arbejdsdag. Hvad bruger man tiden til, har man god tid eller bliver man f.eks. hele tiden forstyrret i sit arbejde?

Studieledernes metaforer om tid afspejler en hverdag, som er svær at planlægge, og som er karakteriseret ved mange afbrydelser, hvilket f.eks. afspejler sig i følgende formuleringer: "Som studieleder har man sjældent et øjebliks fred", "man skal løbe hurtigere end en hest kan rende", "alle forventer et lynhurtigt svar", "forandringsprocessen synes endeløs".

De anvendte metaforer signalerer, at studielederne mangler tid til refleksion og mulighed for at forholde sig langsigtet og strategisk til uddannelse og pædagogik. Derimod forventes man at reagere hurtigt på henvendelser og træffe beslutninger.

Tidsopfattelsen afspejler sig blandt andet gennem de mange bevægelsesmetaforer, som studielederne bruger, når de beskriver deres job. Der er tale om "en strøm af information," eller man oplever "at drukne i opgaver". Man er et "gennemfartssted for informationsstrømme" og "går til et hav af møder", ligesom "opgaverne kommer i bølger".

Mange af formuleringerne er knyttet til det maritime element: "strøm, hav, drukne, bølger". Her er tale om et naturelement, som rummer en stor kraft, og som man ikke direkte har indflydelse på. Det kan fortolkes på den måde, at studielederne oplever, at de er underlagt og prisgivet naturens kræfter og luner modsat kulturkræfter, som man i en vis forstand har indflydelse på og kan påvirke.

En arbejdsdag karakteriseret ved de nævnte tidsrytmer får flere studieledere til at overveje, om de har det rigtige job. Er studieledelse "spild af kostbar tid", spørger en studieleder, mens en anden studieleder taler om "fjollet tid" som et udtryk for, at tiden ikke anvendes meningsfuldt og seriøst, men i stedet bruges på opgaver, man oplever som irrelevante og uvæsentlige.

\section{Rum}

Rum udgør et andet centralt ordningsprincip; er rummet disponibelt og fleksibelt eller stramt struktureret? Kan man vælge sine opgaver, eller føler man sig i stedet underlagt opgaver og krav?

En type metaforer, som går igen i beskrivelserne af studieledernes arbejdssituation, er vægteller massemetaforer; der er f.eks. tale om "et udviklingspres, der ikke stopper". Man oplever, "flere og flere opgaver er lagt på studieledernes skuldre", ligesom "systemet er tungt". Man håber, at der vil ske ændring i studieledernes arbejdsforhold, sådan at "presset lettes fra studielederen". 
I en række af de nævnte eksempler er erfaringen kropsliggjort. Studielederhvervet tynger én, og studielederne kan opleve, at de har svært ved at flytte sig og kan have vanskeligt ved at navigere. Rummet synes stramt struktureret, og de selvstændige navigationsmuligheder er få.

\section{Forholdet til samarbejdspartnere}

De metaforer, som knytter sig til studielederens forhold til omverdenen, dvs. relationer og kontakter til f.eks. kollegaer, studerende, administration og fakultet, peger på en stor kontaktflade og et varieret arbejdsindhold, men vel at mærke et arbejdsindhold, som man ofte ikke har nogen direkte indflydelse på.

De studerende mailer f.eks. om "alt mellem himmel og jord", og man forventes "at svare på alle mulige små og store spørgsmål". Det er irriterede, men også forståeligt. På den ene side vil man som studieleder gerne gøre en forskel for de studerende og hjælpe til med at løse små og store problemer. På den anden side kan man føle sig reduceret til et serviceorgan, som fleksibelt skal stå til rådighed med information om ligegyldige petitesser og detaljer.

Såvel ministerium og universitetets topledelse som fakultetet er principal for studielederen og er som tidligere nævnt i stigende omfang formidler og igangsætter af mange nye styrings- og udviklingsinitiativer. Forholdet til de nævnte principaler kan derfor indimellem opleves anstrengende. Hele tiden pålægges man nye opgaver fra fakultet og ledelse, mens det andre gange er mere uklart, hvem der er afsenderen.

Om forholdet til ministeriet hedder det f.eks., at "det vælter desværre ind med ny lovgivning". Om forholdet til fakultetet, f.eks. dekanatet, hedder det f.eks., at studielederen er underlagt "dokumentationstvang", "pålagte opgaver" eller "kontrol og dokumentation af alt mellem himmel og jord". Metaforerne peger på den manglende frihed, man oplever, når man skal løse opgaver, man ikke selv har valgt eller defineret, og som man tilmed ofte oplever som meningsløse.

Nogle gange er relationen gnidningsfri mellem de forskellige samarbejdspartnere. Man oplever f.eks., at "studielederen er bindeled mellem fagkollegiet og ledelsen". Andre gange er opgavefordelingen uklar mellem forskellige samarbejdspartnere: "Hvem har kasketten til at understøtte løsning af konkrete opgaver?", som en studieleder formulerer det. Eller der foregår en form for forhandling eller kamp om, hvem der skal løse hvilke opgaver. "Jeg ved, at det ikke er mit bord", som en studieleder udtrykker det.

Om forholdet til administrationen og fordelingen af opgaver mellem denne og studieledelse hedder det f.eks.: "Det kunne med fordel rulles tilbage til TAP". På den anden side "skal man passe på med, at der sker en glidning af et valgt og demokratisk organ (studienævnet) til et administrativt organ (TAP-området)".

Om fors $\varnothing$ get på at overtale kollegaer, som man er leder for, men jo er uden ledelsesret over, til at påtage sig opgaver, f.eks. vedrørende undervisning og eksamen, hedder det f.eks. "at man går tiggergang til pressede kolleger".

Metaforerne signaler, at det til tider er uklart, hvem som skal løse hvilke opgaver, og der foregår en løbende forhandling om opgaver med de nærmeste samarbejdspartnere, f.eks. fakultet, kollegaer, studerende og administration. 


\section{Studielederens identitet}

Hvordan forstår studielederne deres primære rolle, funktion og ledelsesopgave? Med andre ord: Hvad er det for metaforer, studielederne gør brug af, når de udtrykker deres primære forståelse af studielederjobbet?

Identitet er ikke en fast størrelse, men bliver altid formuleret i relation til andre erfaringer, roller og positioner (Gergen, 1991). Alle studieledere er forskere (med større eller mindre aktivitetsniveau). Studieledernes vurdering af jobbet afspejler derfor ofte en erfaring, hvor beskrivelse og forståelse af jobbet bliver til som kontrast til forskerjobbet.

Som forsker har man en $h \varnothing j$ grad af autonomi: Man kan inden for visse rammer selv vælge emne, metoder og samarbejdspartnere. I studielederjobbet oplever man derimod ofte en ringe grad af autonomi, tiden er nutidsorienteret, og der er svært at få tid til at fordybe sig. I forskning er tiden ofte fremtidsorienteret og er karakteriseret ved lange tidsrytmer. Studielederjobbet er i stedet ofte præget af mange afbrydelser, uforudsigelighed og krav om hurtig stillingtagen og reaktion.

En metafor, som kan fors $\varnothing$ ge at indkredse denne oplevelse af i høj grad at være underlagt udefrakommende styring og hele tiden skulle stå til rådighed i forbindelse med løsning af småopgaver, kunne være metaforen om studielederen som pedel. Der er her ikke tale om en metafor, som studielederne bruger, når de beskriver deres job, men en metafor, jeg som forsker bringer $\mathrm{i}$ spil i forhold til at tydeligg øre centrale erfaringer ved studielederjobbet.

En pedel er en person, som er ansat til at vedligeholde bygninger og inventar, og som skal stå til rådighed for andres ønsker og behov. Vedkommende har en vis grad af indflydelse på sin arbejdsdag og kan inden for visse rammer vælge arbejdsmetoder og prioritere imellem opgaver. Studieleder-pedellen skal ikke vedligeholde bygninger, men derimod vedligeholde universitetets immaterielle inventar, dvs. universitetsstudier og uddannelser. Studielederen har ofte mulighed for at prioritere sine opgaver, men skal ofte, nøjagtig som pedellen, stå til rådighed for andres $\emptyset$ nsker og behov og løse akut opståede problemer.

Nok en metafor, der passende kan bringes i spil i forhold til at indkredse studielederens identitet, er metaforen nyttig idiot. En nyttig idiot er en person, som udfører andres opgaver, ofte uden at være bevidst om det. En stor del af studielederjobbet går således med at implementere initiativer fra ministerium, topledelse og fakultet, som man ikke nødvendigvis identificerer sig med eller bakker op. Studielederen har her påtaget sig et nødvendigt, men utaknemmeligt job, som kollegaerne ofte ikke gider.

En mere positiv metafor i forhold til at beskrive studieledernes erfaringer og identitet er metaforen maskinmester. Ifølge studieledernes afrapporteringer er det, som giver st $\varnothing$ rst tilfredsstillelse i studielederjobbet, når "tingene kører", ligesom studielederjobbet kan opleves tilfredsstillende, "fordi man er i maskinrummet".

Maskinmestermetaforen associerer til en oplevelse, hvor man får tingene til at glide og fungere. Man er i en form for kontrol og oplever autonomi, måske som kontrast til de oplevelser af udefrakommende tvang og styring og mangel på frihed, der som nævnt er en tilbagevendende erfaring blandt studieledere.

Det er interessant, at det netop er maskinmestermetaforen, som er valgt som billede på det, som giver størst glæde og tilfredsstillelse ved jobbet. Maskinmesteren bestemmer ikke kursen, ligesom kaptajnen gør, og hun sætter heller ikke kursen, sådan som styrmanden gør. Maskinme- 
steren er dog en helt afgørende forudsætning for, at skibet kan sejle, og har derfor organisatorisk set en central og vigtig nøglerolle.

\section{Sammenfatning af analysen}

Sammenfattende viser analysen af studieledernes erfaringer, at de oplever en stor arbejdsbelastning med konstante afbrydelser, hvor en stor del af tiden går med at løse opgaver eller problemer, som de pålægges udefra og i en del tilfælde oppefra. Der er sjældent mulighed for at forholde sig langsigtet og strategisk i jobbet.

Studielederen har en stor kontaktflade og mange samarbejdspartnere. I bedste fald er studielederen en brobygger, dvs. et relevant bindeled mellem forskelige medarbejdergrupper, som sørger for, at information og viden cirkulerer og finder vej til relevante aktører. Samarbejdsrelationerne er både kilde til arbejdsglæde og tilfredsstillelse og til konflikt og problemer. Dog sådan at forholdet til principalen, f.eks. ministerium og fakultet, ofte beskrives negativt. Det er som regel disse, som pålægger studielederen opgaver, vedkommende ikke selv har valgt. Ofte er omverdensrelationen forhandlingsorienteret og indimellem ligefrem konfliktfyldt; det gælder f.eks. i forhold til kollegaer, ledelse og administration. Generelt kan man sige, at relationen til omverdenen er overvejende reaktiv. Som studieleder reagerer man på udefrakommende begivenheder, frem for at man selv er dagsordensættende og initiativskabende.

Den største arbejdstilfredsstillelse i studielederjobbet knytter sig til oplevelsen af at være problemløser og bidrage til, at det store uddannelsesmaskineri kører rundt. Indimellem føler studielederen sig som en velforn $\varnothing$ jet maskinmester, som sørger for at vedligeholde og udvikle studieog uddannelsesmaskineriet, så hverdagen fungerer, og alle når sikkert i havn. Det meste af tiden er studielederen dog snarere en universitetspedel, som skal løse simple driftsspørgsmål uden at have tid til eller mulighed for at involvere sig i opgaver af strategisk og udviklingsmæssig karakter.

Den grundlæggende identitet som studieleder svinger mellem en positiv identitet som henholdsvis maskinmester og brobygger samt en mere negativt formuleret identitet som pedel og nyttig idiot, dog sådan at det ofte er de sidstnævnte, der dominerer.

\begin{tabular}{|l|l|l|l|l|}
\hline Metafor & $\begin{array}{l}\text { Forhold til om- } \\
\text { verden }\end{array}$ & Tid & Rum & Primær identitet \\
\hline Maskin-mester & $\begin{array}{l}\text { Horisontal og } \\
\text { dialogisk }\end{array}$ & Nutid/-fremtid & $\begin{array}{l}\text { Fleksibel: } \\
\text { Indflydelse på valg } \\
\text { af opgaver }\end{array}$ & $\begin{array}{l}\text { Central problemlø- } \\
\text { ser og vedligeholder }\end{array}$ \\
\hline Brobygger & $\begin{array}{l}\text { Horisontal og } \\
\text { dialogisk }\end{array}$ & Nutid/fremtid & $\begin{array}{l}\text { Fleksibel: } \\
\text { Indflydelse på valg } \\
\text { af opgaver }\end{array}$ & Kommunikator \\
\hline Pedel & $\begin{array}{l}\text { Vertikal } \\
\text { /horisontal }\end{array}$ & Nutid & $\begin{array}{l}\text { Struktureret: } \\
\text { Begrænset indfly- } \\
\text { delse på valg af } \\
\text { opgaver }\end{array}$ & Vedligeholder \\
\hline Nyttig idiot & Vertikal/hierarkisk & Nutid & $\begin{array}{l}\text { Stramt } \\
\text { struktureret: } \\
\text { Ringe indflydelse } \\
\text { på valg af opgaver }\end{array}$ & $\begin{array}{l}\text { Implementerings- } \\
\text { agent }\end{array}$ \\
\hline
\end{tabular}

Figur 1: Erfaringer med studieledelse 


\section{Studielederen som leder}

Størstedelen af studieledernes tid bliver brugt på drift og tilpasning og kun i mindre grad på udviklingsorienterede opgaver (Johnsen, 1998). I ledelsestermer arbejder studieledere primært med management og ikke med strategisk ledelse. I sin bog om mellemledelse skitserer Voxted (2007, s. 140 ff.) forskellige mellemlederpositioner. Den traditionelle mellemleder arbejder med faglig ledelse og drift. Den hybride mellemleder arbejder ligeledes med drift og faglig ledelse, men også med emner som personaleledelse, strategisk arbejde og forandringsledelse. Overordnet set har den hybride mellemleder til formål at bygge bro mellem topledelsens mere strategiske tilgang og de ansattes mere faglige tilgang. Studieledelse under den decentrale model tenderer i høj grad mod en mere traditionel mellemlederfunktion, hvor de primære opgaver er faglig ledelse og drift (Voxted, 2007).

Den ledelsesrolle, studielederen varetager, kan fortolkes i sammenhæng med den modernisering, som universiteterne gennemgår i disse år, og som finder sted i forbindelse med det, som er blevet kaldt overgangen til konkurrencestaten (Pedersen, 2011; Nørgaard \& Kaspersen, 2015; Petersen, 2016). Universiteterne har her ændret sig, så der i stigende grad orienteres hen imod arbejdsmarkedets ønsker og behov (Jarvis, 2007; Ball, 2012: Altbach et al, 2009), hvorfor mængden af centrale initiativer er taget til. Studielederen bliver direkte og indirekte agent for denne udvikling og skal fors $\varnothing$ ge at navigere i en spændingsfyldt position mellem statens og topledelsens moderniseringsdagsorden og den mere traditionelle faglige og kollegialt orienterede dagsorden.

\section{Refleksioner over studiet}

Studiet har ikke tegnet et særligt attraktivt billede af erfaringerne med studieledelse. Det kan ikke udelukkes, at en del af de identificerede problemstillinger er knyttet til den decentrale model, som er unders $\emptyset$ gt. Der er dog en række af de beskrevne tendenser, som med stor sandsynlighed er af generisk karakter, og som afspejler problemstillinger, som vedrører studieledelse generelt. Der er klare paralleller til den erfaringsverden, som bliver tegnet $\mathrm{i}$ analysen her og til Thomas Harboes (2013) ph.d. afhandling om studieledernes ledelsesformer, som inddrager et bredt udvalgt af studieledere ved danske universiteter, og som er det eneste st $\varnothing$ rre danske studie, som findes af området. En undersøgelse, som inddrager flere universiteter, evt. i kombination med en nationalt anlagt survey-unders $\varnothing$ gelse, ville kunne bidrage til at give et bredere signalement af studieledernes erfaringer og udfordringer, end dette studie har gjort.

\section{Perspektiver for studieledelse}

Kan man gøre noget for, at studielederen opnår bedre vilkår for at arbejde med studieledelse med større fokus på udvikling af uddannelse og undervisning, sådan at studielederen ikke tvinges over i rollen som reaktiv driftsleder, sådan som studiet har peget på, men i højere grad får mulighed for at arbejde med opgaver, der er relateret til udvikling og strategier? I det følgende skal tre forskellige perspektiver for udvikling af studielederfunktionen diskuteres.

Et perspektiv kunne være at professionalisere funktionen, sådan at man har mulighed for at arbejde på fuld tid med studieledelse og ikke skal undervise og forske samtidig. Den model har man valgt på visse universitetsfakulteter. Der er en del fordele knyttet til den nævnte model. Ideelt set har man tid og mulighed for i højere grad at arbejde udviklingsorienteret og strategisk med pædagogik og uddannelse i modsætning til nu, hvor man i høj grad arbejder med drift, tilpasning og management.ii Som det er nu, ligger den strategiske ledelsesopgave typisk hos pro- 
dekanerne (Harboe, 2013, s. 118) eller hos universitetets topledelse, som i stigende grad formulerer strategier, som så implementeres ned igennem den hierarkiske ledelsesmodel, hvor studielederen er agent.

Professionaliseringsstrategien har dog som konsekvens, at man forskyder problemer nedad, sådan at man er $n \varnothing d t$ til på de enkelte uddannelser at have en slags reelt fungerende studieleder, f.eks. benævnt uddannelseskoordinator, som har føling med de daglige opgaver, problemer og udfordringer.

En anden mulighed, i forlængelse af kritikken af den eksisterende struktur, er, sådan som f.eks. Udvalget for Kvalitet og Relevans for de Videregående Uddannelser (2015) er fremkommet med, at indføre en slags superstudieledere, som såvel har ledelsesret som personaleansvar. Formålet er at opprioritere ledelse og kvalitetsudvikling af universitetets uddannelser og sikre et tydeligt ledelsesmæssigt ansvar, som kan understøtte uddannelseskvalitet og prioriteringen af undervisningen. Man kunne kalde det for topledelsesstrategien. Et af problemerne er, at man indfører nok et ledelseslag inden for den hierarkiske ledelsesmodel, som ikke har føling med undervisere og studerendes hverdag, og som heller ikke er forankret i det kollegiale selvstyre.

En tredje strategi, som kunne kaldes aflastningsstrategien, er at overlade stadigt flere studieledelsesopgaver til det administrative personale med henblik på at aflaste studielederne. Den model er indført flere steder, hvor opgaver knyttet til studienævnene og studieledelse overdrages til studienævnssekretærer, studiekoordinatorer og $\varnothing v$ rigt TAP-personale. Dette er en mulighed, men dels har nogle studieledere svært ved at afgive ansvar og kompetence, dels kan det bidrage til at indholdst $ø$ mme funktionen og kan skabe grænseproblemer til administrationen (Harboe, 2015).

\section{Professionaliseringsstrategien som et muligt bud på styrkelse af studieledelsen}

De forskellige universiteter har valgt forskellige løsninger, hvilket afspejler forskellig historie og traditioner. Der er ikke kun én måde at være studieleder på, men en udvikling, hvor der fyldes flere og flere opgaver på studieledelsesfunktionen, sådan som studielederne i undersøgelsen oplever det, er problematisk i forhold til rekruttering og fastholdelse af kompetente studieledere samt udvikling af universitær uddannelse og pædagogik. I forhold til de erfaringer med studieledelse, som analysen har peget på, skal der argumenteres for behovet for i højere grad at skabe rum for udviklingen af en professionaliseringsstrategi med adgang til uddannelse og kvalificering og med større ansvar og kompetence. Studielederen vil her i højere grad kunne agere som hybrid mellemleder, hvor fokus ikke kun primært er på drift og faglig ledelse, men i højere grad på mere strategisk orienterede ledelsesopgaver (Voxted, 2007). En sådan strategi vil ideelt set også give bedre mulighed for, at studielederen kan agere mere informationskompetent, dvs. inddrage pædagogik, forskning og systematisk information i arbejdet med studieledelse (Harboe et al, 2017).

Den decentrale model, som har dannet afsæt for analyserne, kan lyde sympatisk og nyder også opbakning i de kollegiale miljøer. Set i et politisk eller konfliktuelt perspektiv (Borum, 2013) er der imidlertid en risiko for, at studielederne forvandles til nyttige idioter, universitetspedeller eller reaktive driftsledere. En sådan organisering bevirker nemlig, at det reelt er en top-downstrategi, som dominerer universitetet som organisation. Studielederne druknes i alt for høj grad $\mathrm{i}$ administrative opgaver, som de reagerer reaktivt på, sådan som analysen viser. 
Under den decentrale model fremstår studielederne som svage ledere uden tiltrækkelige strategiske og selvstændige manøvremuligheder, som ikke formår at give institutledelse, fakultet og universitetets topledelse et tilstrækkeligt modspil. Dette hænger blandt andet sammen med, at de ikke har mulighed for at hellige sig funktionen fuldt ud. Dermed får de svært ved at positionere sig i forhold til de nævnte organer, og de har kun i ringe grad mulighed for at komme med et kvalificeret modspil til den strøm af centrale tiltag, de møder.

En svag studieledelse medfører en stor risiko for, at uddannelse, forskning og f.eks. rekrutteringspolitik afkobles, og at teknokratiske løsninger dominerer, fordi den stemme, som er tættest på studerende, kollegaer og uddannelseshverdagen, ikke har tid til eller mulighed for at positionere sig.

Harboes (2013) studie viser, at studieledere er uformelle ledere, som leder via forhandling, tillid og overtalelse. En stor del af ledelsesopgaven er at gøre brug af såkaldt soft teknologi, dvs. overtalelse, forhandling og fortolkninger, hvilket ofte kendetegner jobbet som mellemleder inden for uddannelsessektoren (Frederiksen, 2016; Raae, 2016).

Den pågældende ledelsesform er selvfølgelig umiddelbart sympatisk, fordi den forudsætter tillid og opbakning i det kollegiale miljø. Der er dog tale om en ledelsesform, som i alt for høj grad er personafhængig. I en tid, hvor såvel interne som eksterne krav og tiltag er stigende, er der behov for en stærkere stemme, som er i stand til at mobilisere det nødvendige modspil til den centralisering, standardisering og markedsgørelse, de universitære studie- og uddannelsesmiljøer konfronteres med. En professionalisering af studielederfunktionen kan være et bud.

\begin{tabular}{|l|l|l|l|l|}
\hline $\begin{array}{l}\text { Studieleder- } \\
\text { strategi }\end{array}$ & Arbejdstid & $\begin{array}{l}\text { Centrale } \\
\text { opgaver }\end{array}$ & Fordele & Ulemper \\
\hline $\begin{array}{l}\text { Professiona- } \\
\text { liserings- } \\
\text { strategi }\end{array}$ & $\begin{array}{l}\text { Fuldtids- } \\
\text { studieleder }\end{array}$ & $\begin{array}{l}\text { Strategi, udvik- } \\
\text { ling, en del af } \\
\text { ledelsen }\end{array}$ & $\begin{array}{l}\text { Mere tid til studie- } \\
\text { ledelse, indflydelse } \\
\text { på strategi og ud- } \\
\text { vikling }\end{array}$ & $\begin{array}{l}\text { Problemer forsky- } \\
\text { des nedad i organi- } \\
\text { sationen, ingen } \\
\text { direkte kontakt } \\
\text { med undervisning } \\
\text { og uddannelse }\end{array}$ \\
\hline $\begin{array}{l}\text { Topledelses- } \\
\text { strategi }\end{array}$ & $\begin{array}{l}\text { Fuldtids- } \\
\text { studieleder }\end{array}$ & $\begin{array}{l}\text { Personalele- } \\
\text { delse, ledelses- } \\
\text { ret, } \\
\text { rekruttering, } \\
\text { strategi, udvik- } \\
\text { ling }\end{array}$ & $\begin{array}{l}\text { Indflydelse på stra- } \\
\text { tegi og udvikling, } \\
\text { indflydelse på re- } \\
\text { kruttering og med- } \\
\text { arbejderudvikling }\end{array}$ & $\begin{array}{l}\text { Ikke forankret i det } \\
\text { kollegiale miljø, } \\
\text { ingen direkte kon- } \\
\text { takt med uddan- } \\
\text { nelse og undervis- } \\
\text { ning }\end{array}$ \\
\hline $\begin{array}{l}\text { Aflastnings- } \\
\text { strategi }\end{array}$ & $\begin{array}{l}\text { Deltids- } \\
\text { studieleder }\end{array}$ & $\begin{array}{l}\text { Primært } \\
\text { driftsopgaver }\end{array}$ & $\begin{array}{l}\text { Mere tid til kerne- } \\
\text { opgaven }\end{array}$ & $\begin{array}{l}\text { Grænseproblemer } \\
\text { til administratio- } \\
\text { nen, primær fokus } \\
\text { på driftsopgaver }\end{array}$ \\
\hline
\end{tabular}

Figur 2: Perspektiver for studieledelse 
Finn Wiedemann (f. 1964) er ansat som lektor ved Institut for Kulturvidenskaber og studieleder for Pædagogik v. Syddansk Universitet. Han forsker i uddannelse, pædagogik og ledelse.

Senest har han udgivet bøgerne 'Uddannelse under naturlig forandring', Syddansk Universitetsforlag, 2017, og 'Send mere ledelse - en analyse af Ledersamfundets konsekvenser', Syddansk Universitetsforlag, 2016.

\section{Referencer}

Alvesson, M. \& Spicer A. (2011). Metaphors we lead by. New Yourk: Routledge.

Altbach, P.G., Reisberg \& L. Rumbley L.E. (2009). Trends in global higher education: Tracking an academic revolution. UNESCO.

Ball, S. J. (2012). Global Education Inc.: New Policy Networks and the Neoliberal Imaginary. London: Routledge.

Borum, F. (2013). Strategier for organisationsændringer. Kbh.: DJØF.

Frederiksen, L. F. (2016). Mellem hvad - hvad er op og ned i hierarkiet I: Dion Russelbæk og Jakob Ditlev Bøje (Red.), Mellem ledere. Uddannelsesledelse som problem eller svar. (s. 4365). Odense: Syddansk Universitetsforlag.

Gergen, K. (1991). The Saturated Self. Dilemmas of Identity in Contemporary Life. New Yourk: Basic Books.

Gibbons, M., Limogens, C \& Nowotny, H. (1994). The new Production of Knowledge. London: Sage.

Greve, C. \& Ejersbo, N. (2014). Moderniseringen af den offentlige sektor. Kbh.: Akademisk Forlag.

Gullestrup, H. (2003). Kulturanalyse - en vej til tværkulturel forståelse. Kbh.: Akademisk Forlag.

Harboe, T. (2013). Subtil ledelse i en ny og mere insisterende form - et kvalitativt studie af studieledere ved danske universitetet. Odense: Syddansk Universitetsforlag (ph.d. afhandling)

Harboe, T. (2015). Danske studieledere står ved en kritisk skillevej. Dansk Universitetspædagogisk tidsskrift, 19. s. 22-32.

Harboe, T. Rump, C. Ф, Hyldegård, J. og Bruun, J. (2017): Informationskompetente studieledere om sammenhænge mellem studielederes brug af videnskilder og deres ledelsestilgange, Dansk Universitetspædagogisk tidskrift, 22. s. 48-63.

Hatch, M. J., Kostera, M., Kozminski, A. (2006). The three factors of leadership and fellowship: manager, artist, priest in: Organizational Dynamics, 35 (1) s. 355-382.

Hood, C. (1991). A Public Management for all Seasons?, Public Administration, 69, s.. 3-19.

Universitetsloven: https://danskelove.dk/universitetsloven. Hentet 24. august. 2017

Jarvis, P. (2007). Globalization, Lifelong Learning and The Learning Society. Sociological Perspectives. London \& New Yourk: Routledge.

Johnsen, E. (1982). Lærer, ledelse og skoleledelse. Frederikshavn: Dafolo.

Kaspersen, L. B. \& Nørgaard J. (2015). Ledelseskrise i konkurrencestaten. Kbh.: Hans Reitzels Forlag. 
Klausen, K. K. \& Ståhlberg K. (red.) (1998). New Public Management i Norden - Nye organisationsforme i den decentrale velfærdsstat. Odense: Odense Universitet.

Knudsen, T. (2007). Fra folkestyre til markedsdemokrati. Kbh. Akademisk Forlag.

Lakoff, G. \& Johnson M. (2004). Hverdagens metaforer. Kbh.: Hans Reitzels Forlag.

Lévi-Strauss, C. (1994). Den vilde tanke. Kbh.: Gyldendal.

Morgan, G. (1997). Images of Organizations. London: Sage Publications.

Nye veje og høje mål. Kvalitetsudvalgets samlede analyserapport (2015): Udvalget for Kvalitet og relevans for de videregående uddannelser.

http://ufm.dk/publikationer/2015/nye-veje-og-hoje-mal/nye-veje-og-hoje-mal-samletanalyserapport.pdf. Hentet d. 24. august. 2017

Pedersen, D. (2008). Når ledelsespositionen er til forhandling - det dynamiske ledelsesrum myten om den suveræne leder in: Erik Elgaard Sørensen et al. (Red.): Ledelse og læring - $i$ organisationer (s. 198-223). Kbh.: Hans Reitzels Forlag.

Pedersen, Ove K. (2011). Konkurrencestaten. Kbh.: Hans Reitzels Forlag.

Petersen, J. H. (2016). Luther og konkurrencestaten. Odense: Syddansk Universitetsforlag.

Raae, P. H. (2016). Effektive mellemledere - Når effektivitetskrav møder gymnasiet I: Dion Russelbæk og Jakob Ditlev Bøje (Red.): Mellem ledere. Uddannelsesledelse som problem eller svar. (s.107-127) Århus: Klim.

Schultz, M. (2000). Kulturer i organisation. Funktion eller symbol. Kbh.: DJØF.

Vosmer, J. (1969). Værkets verden, værkets holdning, Kritik nr. 12.

Voxted, S. (2007). Den ny mellemleder. Kbh.: Hans Reitzels Forlag

Wiedemann, F. (2016). Send mere ledelse. En analyse af Ledersamfundets konsekvenser. Odense: Syddansk Universitetsforlag.

Wiedemann, F. (2017). Uddannelsens naturlige forandring. Odense: Syddansk Universitetsforlag.

Wright, S. (2014). Knowledge That Counts: Points Systems and the Governance of Danish Universities I: Alison Griffith Smith (Red.), Under new public management: institutional ethnographies of changing front-line work (s. 294-338). Dorothy. Toronto: University of Toronto Press.

\footnotetext{
' I visse tilfælde kan studieledere have en selvstændig økonomi.

ii Harboe (2015) nævner, at strukturer, hvor studieledere kan finde bedre tid og plads til at arbejde med det strategiske område, er under vej ved flere universiteter.
} 